Both systems employ an aluminium platen that Haake says assures even heat distribution, eliminating the "smile" effect. The sequencers have a thermoregulated design, and can be set for high-speed, high-voltage runs or at lower voltages for overnight runs. The separating gel for the $\$ 1,885$ (US) $100 \mathrm{~cm}$ DNA sequncer is 95 $\mathrm{cm}$ in length, allowing over 200 nucleotides to be read at a single loading, and is compatible in size with the $22 \times 100 \mathrm{~cm}$ HBI Transfilm for autoradiography. The $\$ 1,595$ (US) $45 \mathrm{~cm}$ sequencer's gels can be used with standard $35 \times 43 \mathrm{~cm}$ X ray films.

In addition to its Retro-Tek AIDS virus kits and probes, Cellular Products will be showing its Cellkines line of human immune cell culture products in booth 30 (Reader Service No. 112). Cellular Products has a full line of growth factors, including human $\mathrm{T}$-cell growth factor, human B-cell growth factor and human platelet-derived growth factor, which sell for $\$ 47.50$ to $\$ 195$ (US), depending upon

\section{Molecular biology becoming more fashionable?}

DR Ruth Kavenofi, a cell biologist studying chromosome structure at the University of California, San Diego, is bent on bringing the beauty of science to the general populace. Through her work with electron microscopy, she has imaged "sprung" $\boldsymbol{E}$. coli DNA molecules, confirming the DNA supercoiling model set down by Worcel and Burgi'. Her technique employs an aqueous salt solution, instead of the usual formamide solution, and the result is a much clearer view of the DNA loops involved in the supercoil. The aesthetic appeal of the resulting spread molecule led her first to produce wall posters of the image to decorate the laboratories of friends and associates. From there, she went on to print her images on more popularized items, such as postcards and T-shirts, and her company, Designer

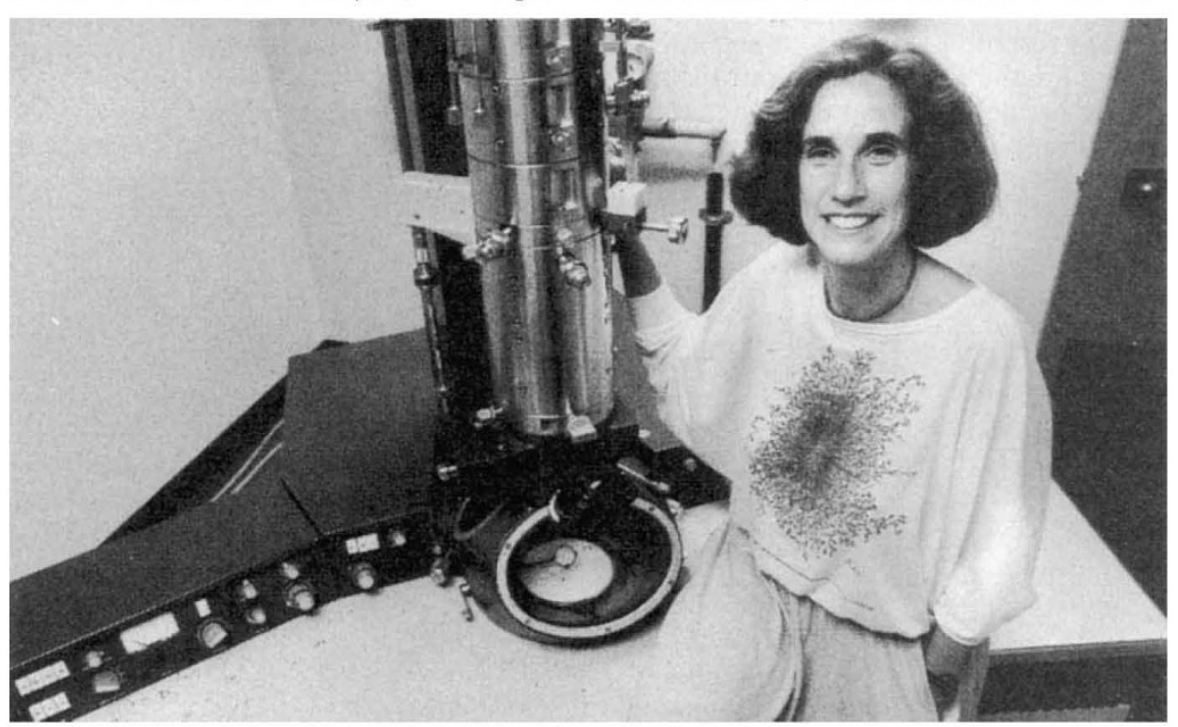

Dr Kavenoff seated by the source of her images, wearing one of her DesignerGenes shirts. size desired. For detecting the HTLV-1 core protein, p19, Cellular Products offers anti-p19 monobody costing $\$ 175$ (US) for 100 tests. Human immune (gamma) interferon is also available from Cellular Products, for purely in vitro diagnostic use.

Seikagaku America, in booth 39 , will be showing its molecular cloning products (Reader Service No. 113). At the top of the list will be Seikagaku's reverse transcriptase, for the synthesis of complementary DNA to mRNA. Seikagaku sells the reverse transcriptase in 2,000 unit sizes for $\$ 240$ (US), and in 5,000 unit sizes for $\$ 500$ (US), and defines a unit as the amount of enzyme which incorporates one nanomole of dTMP into acid-insoluble product in 10 minutes at $35^{\circ} \mathrm{C}$.

The PS 200 automated DNA synthesizer will be dominating attention in the Cruachem booth, number 40 , but the company representatives are also likely to be showing off their new 1987 catalogue

Genes, was born. Her range of products, that now includes labcoats, sweatshirts, and totebags, all come with an explanation of the image they bear, and a bit of background on DNA in general (Reader Service No. 116). Other images are currently in the pipeline, including micrographs of chloroplast DNA (GreenGenes), antibody mRNA and DNA (A Splice of Life), and flu virus DNA (The Usual Suspect). In this manner, Dr Kavenoff hopes to increase the level of knowledge of molecular biology held by the hoi polloi. It is her opinion that "people are reluctant to fund research they don't understand," and she seeks to improve this understanding. A variety of DesignerGenes products are now distributed by Carolina Biological Supply Company, Burlington, North Carolina, 27215.

1. Worcel, A. \& Burgi, E. J. molec. Biol. 71, 127-147 (1972).

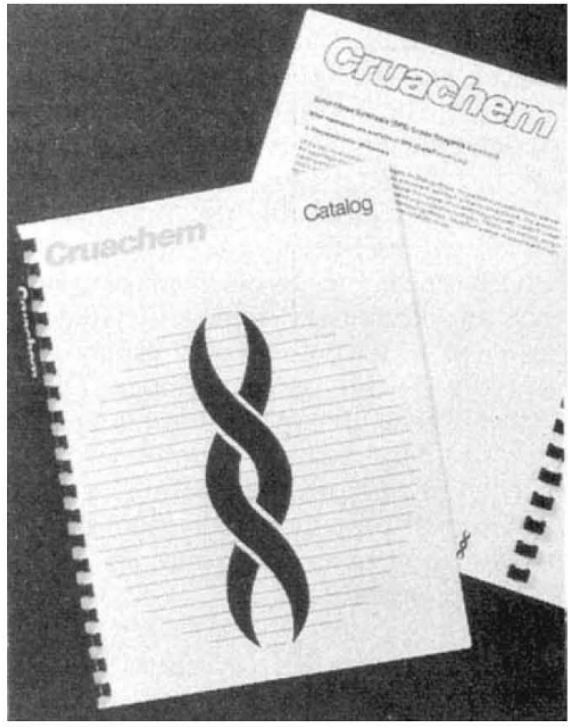

The book on DNA synthesis reagents.

(Reader Service No. 114). The catalogue features solid phase synthesis (SPS) grade chemicals and reagents, including Cruachem's CE cyanoethylphosphoramidites for "easy on the nose" DNA synthesis. Cruachem's One Shot phosphotriester starter kit simplifies manual or semiautomated DNA synthesis by using singleuse packs containing enough material for 100 coupling reactions on a 1 micromolar scale. ColorTag monomers provide visual verification of sequence during synthesis, so unsatisfactory syntheses can be stopped before costly reagents are wasted.

Made just for researchers performing routine subcloning, GIBCO/BRL in booths 34 and 35 offers Subcloning Efficiency competent cells (Reader Service

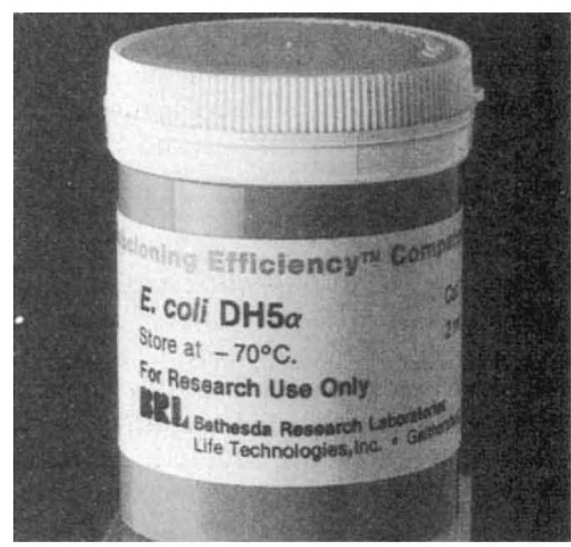

Increases the level of uptake of plasmid DNA.

No. 115). GIBCO/BRL says use of its competent cells yields consistent numbers of greater than $1 \times 10^{6}$ transformants per microgram of monomer plasmid DNA, at less than one-eighth the price per reaction of other commercially available competent cells. The DH5 alpha recA1 marker ensures the stability of inserts, and its endA1 marker improves the quality of plasmid DNA prepared from mini-preps. GIBCO/BRL's competent cells cost \$37 (US) for a $2 \mathrm{ml}$ sample. 